\title{
Perubahan Arus Kas dan Pengaruhnya terhadap Return Saham
}

\author{
Rihfenti Ernayani $^{1}$, C. Prihandoyo ${ }^{2}$, Abdiannur $^{3}$ \\ ${ }^{1,2,3}$ Fakultas Ekonomi, Universitas Balikpapan
}

rihfenti@uniba-bpn.ac.id

\begin{abstract}
Manufacturing companies is companies whose activities manage raw materials into finished goods and then sell them to consumers. Manufacturing companies had a large scale of production and require substantial capital for product development and market share expansion, making it attractive to investors to know whether the company's cash flow from operating activities, investment activities and financing activities have an effect on stock returns. This research is a quantitative research with the aim to test and prove empirically the effect of changes in operating cash flow, changes in investment cash flows and changes in cash flow funding either partially or simultaneously to stock returns. The sample used is a manufacturing company listed on the Indonesia Stock Exchange (IDX) period 2012-2015. Sampling technique using purposive sampling. The data were analyzed by multiple linear regression analysis using SPSS 20 program. The result showed that partially changes of operating cash flow had an effect on stock return, investment cash flow change has no effect on stock return, and changes from funding cash flow has no effect on stock return, simultaneously changes from operating cash flow, changes from / into investment cash flow and changes in cash to flow financing effect on stock returns.
\end{abstract}

Keywords: operating cash flow, investing cash flow, financing cash flow, stock return

\begin{abstract}
Abstrak
Perusahaan manufaktur merupakan perusahaan yang aktivitasnya mengelola bahan mentah menjadi barang jadi kemudian menjualnya kepada konsumen. Perusahaan manufaktur memiliki skala produksi yang cukup besar dan membutuhkan modal yang besar untuk pengembangan produk dan ekspansi pangsa pasarnya, sehingga cukup menarik bagi investor untuk mengetahui apakah arus kas perusahaan yang berasal dari aktivitas operasi, aktivitas investasi dan aktivitas pendanaan mempunyai pengaruh terhadap return saham. Penelitian ini merupakan penelitian kuantitatif dengan tujuan untuk menguji dan membuktikan secara empirik pengaruh perubahan arus kas operasi, perubahan arus kas investasi dan perubahan arus kas pendanaan baik secara parsial maupun secara simultan terhadap return saham.Sampel yang digunakan adalah perusahaan manufaktur yang terdaftar di Bursa Efek Indonesia (BEI) periode 2012-2015. Teknik pengambilan sampel menggunakan purposive sampling. Data dianalisa dengan analisis regresi linier berganda menggunakan program SPSS 20.Hasil penelitian menunjukkan bahwasecara parsial perubahan arus kas operasi berpengaruh terhadap return saham, perubahan arus kas investasi tidak berpengaruh terhadap return saham, dan perubahan arus kas pendanaan tidak berpengaruh terhadap return saham, sedangkan secara simultan perubahan arus kas operasi, perubahan arus kas investasi dan perubahan arus kas pendanaan berpengaruh terhadap return saham.
\end{abstract}

Kata kunci : arus kas operasi, arus kas aktivitas investasi, arus kas aktivitas pendanaan, return saham

\section{Pendahuluan}

Pasar modal merupakan sarana untuk menyalurkan dana yang bersumber dari masyarakat ke berbagai sektor untuk melaksanakan aktivitas investasi perusahaan dalam bentuk surat-surat berharga. Salah satu jenis investasi surat berharga adalah saham.Saham merupakan sebuah bukti kepemilikan atau penyertaan modal dalam sebuah perusahaan atau perseroan terbatas sebagai tanda bahwa telah ikut menanamkan modal didalam 
pembiayaan kegiatan operasional perusahaan tersebut. Tujuan investor berinvestasi dipasar modal adalah untuk mendapatkan pengembalian atau return. Seorang investor yang rasional akan sangat memperhatikan hasil pengembalian saham karena return saham merupakan salah satu indikator untuk mengetahui keberhasilan suatu investasi (Yocelyn, Azilia, \& Christiawan, 2012).

Saham adalah sebuah bukti penyertaan modal dalam sebuah perusahaan (Hadi, 2013), sedangkan return saham merupakan keuntungan yang diperoleh dari kepemilikan saham investor atas investasi yang dilakukan. Return saham dibedakan menjadi dua jenis yaitu realized return dan expected return. Expected return penting karena digunakan sebagai salah satu pengukur kinerja dari perusahaan (Hartono, 2013).Agar investor merasa aman untuk berinvestasi, investor harus bisa mengukur risiko serta memperkirakan pendapatan yang akan diperolehnya.Informasi yang dibutuhkan oleh investor untuk mengetahui harga saham perusahaan salah satunya adalah laporan keuangan. Dalam laporan keuangan disajikan antara lain laporan laba rugi, laporan posisi keuangan dan laporan arus kas beserta komponennya, yang dapat digunakan oleh para investor untuk memprediksi sekuritas saham.Laporan arus kas ditujukan untuk melaporkan penerimaan dan pengeluaran kas selama satu periode yang berasal untuk melaporkan penerimaan dan pengeluaran kas selama satu periode yang berasal dari aktivitas operasi, pendanaan, dan investasi.Pemakai laporan keuangan dapat menggunakan arus kas sebagai dasar untuk menilai kemampuan perusahaan dalam menghasilkan kas serta setara kas, maupun untuk menilai perusahaan dalam kemampuan menggunakan arus kas tersebut, serta kepastian perolehannya.

Aktivitas operasi merupakan aktivitas penghasil utama pendapatan perusahaan dan aktivitas lain yang bukan merupakan aktivitas investasi dan pendanaan. Aktivitas operasi terkait dengan pos-pos laporan laba rugi dan pospos operasi dalam neraca (Subramanyam \& Jhon, 2011). Umumnya aktivitas operasi berasal dari transaksi dan peristiwa lain yang mempengaruhi penetapan laba atau rugi bersih, dan merupakan indikator yang menentukan apakah dari operasi perusahaan dapat menghasilkan kas yang cukup untuk melunasi pinjaman, memelihara kemampuan operasi perusahaan, membayar dividen dan melakukan investasi baru tanpa mengandalkan pada sumber pendanaan dari luar.

Livnat \&Zarowin (1990) yang menguji komponen arus kas menemukan bukti bahwa komponen arus kas 
mempunyai hubungan yang lebih kuat dengan return saham dibanding hubungan total arus kas dengan return. Menurut Ali (1994) yang telah melakukan penelitian dengan model non linear memberikan bukti adanya nilai tambah kandungan informasi arus kas operasi untuk kelompok perusahaan dengan nilai absolute unexpected cashflows from operations yang tinggi.Pradhono\& Setiawan (2004) menyimpulkan bahwa arus kas operasi memiliki pengaruh terhadap return saham, namun Cahyani (1999), Kurniawan dan Indriantoro (2000) menyatakan bahwa tidak terdapat hubungan antara arus kas operasi dengan return saham.

Aktivitas investasi merupakan cara untuk memperoleh dan menghapuskan aset non kas. Aktivitas ini meliputi aset yang diharapkan untuk menghasilkan pendapatan bagi perusahaan, seperti pembelian dan penjualan aset tetap dan investasi, dalam efek. Aset ini juga meliputi pemberian pinjaman dan penagihan pokok pinjaman (Subramanyam \& Jhon, 2011).Dalam Pernyataan Standar Akuntansi Keuangan tahun 2015 No. 2 Aktivitas investasi adalah aktivitas yang menyangkut perolehan atau pelepasan aktiva jangka panjang (aktiva tidak lancar) serta investasi lain nya yang tidak termasuk dalam setara kas, mencakup aktivitas meminjam uang dan mengumpulkan piutang tersebut serta memperoleh dan menjual investasi dan aktiva jangka panjang produksi. Pengungkapan terpisah arus kas berasal dari aktivitas investasi perlu dilakukan sebab arus kas tersebut mencerminkan penerimaan dan pengeluaran kas sehubungan dengan sumber daya yang bertujuan untuk menghasilkan pendapatan dan arus kas masa depan. Menurut Miller dan Rock (Daniati, 2006) yang melakukan pengujian mengenai pengaruh investasi pada return saham. Hasil studi ini menemukan bahwa peningkatan investasi berhubungan dengan peningkatan arus kas masa yang akan datang dan mempunyai pengaruh positif dengan return saham pada saat pengumuman investasi baru.

Aktivitas pendanaan adalah aktivitas yang mengakibatkan perubahan dalam jumlah serta komposisi ekuitas dan pinjaman perusahaan. Arus kas pendanaan berguna untuk memprediksi klaim terhadap arus kas masa depan oleh para pemasok modal perusahaan. Dalam Pernyataan Standar Akuntansi Keuangan tahun 2015 No. 2 Aktivitas pendanaan adalah kegiatan pendapatan sumber dana dari pemilik dengan memberikan prospek penghasilan dari sumber dana tersebut, meminjam dan membayar hutang kembali, atau melakukan pinjaman jangka panjang untuk membayar hutang tersebut. Pengungkapan terpisah arus kas yang berasal dari aktivitas pendanaan penting 
dilakukan karena berguna untuk memprediksi klaim atas arus kas masa depan oleh para penyedia modal entitas. Menurut Miller dan Rock (Daniati, 2006) menjelaskan bahwa pasar akan bereaksi negatif terhadap pengumuman pendanaan dari kas karena akan berpengaruh terhadap arus kas dari operasi yang lebih rendah untuk masa yang akan datang, selain itu ia juga mengidentifikasi adanya sinyal lain yang berpengaruh terhadap arus kas dari pendanaan yaitu perubahan dividen yang sangat erat hubungannya dengan return saham.

Perusahaan manufaktur merupakan perusahaan yang aktivitasnya mengelola bahan mentah atau bahan baku sehingga menjadi barang jadi lalu menjualnya kepada konsumen. Perusahaan manufaktur memiliki skala produksi yang cukup besar dan membutuhkan modal yang besar pula untuk pengembangan produk dan ekspansi pangsa pasarnya, sehingga cukup menarik bagi investor untuk mengetahui apakah arus kas perusahaan yang berasal dari aktivitas operasi, aktivitas investasi dan aktivitas pendanaan mempunyai pengaruh terhadap return saham.

Berdasarkan latar belakang tersebut, maka yang menjadi permasalahan dalam penelitian ini adalah sebagai berikut: (1) Apakah perubahan arus kas operasi mempunyai pengaruh terhadap return saham?, (2) Apakah perubahan arus

kas investasi mempunyai pengaruh terhadap return saham, (3) Apakah perubahan arus kas pendanaan mempunyai pengaruh terhadap return saham?. (4) Apakah perubahan arus kas operasi, arus kas investasi dan arus kas pendanaan mempunyai pengaruh terhadap return saham. (5) Seberapa besar pengaruh perubahan arus kas operasi, arus kas investasi dan arus kas pendanaan terhadap return saham?.

Berdasarkan paparan tersebut, maka tujuan umum penelitian ini adalah untuk menguji dan menganalisis; pengaruh perubahan arus kas operasi, perubahan arus kas investasi dan perubahan arus kas pendanaan terhadap return saham pada perusahaan manufaktur yang terdaftar di Bursa Efek Indonesia.Selanjutnya, berdasarkan kajian teoritik dan empirik, maka dirumuskan hipotesis penelitian sebagai berikut: (1) Perubahan arus kas operasi berpengaruh terhadap return saham, (2) Perubahan arus kas investasi berpengaruh terhadap return saham, (3) Perubahan arus kas pendanaan berpengaruh terhadap return saham, (4) Perubahan arus kas operasi, arus kas investasi dan arus kas pendanaan berpengaruh terhadap return saham pada perusahaan manufaktur yang terdaftar di Bursa Efek Indonesia.

\section{Metode Penelitian}




\subsection{Variabel}

Jenis penelitian ini merupakan penelitian kuantitatif. Adapun variabel yang digunakan ada dua yaitu variabel dependen dan variabelindependen. Variabel dependen dalam penelitian ini yaitu return saham dan variabel independennya adalah perubahan arus kas (arus kas operasi, arus kas investasi dan arus kas pendanaan).

\section{Perubahan Arus Kas Operasi (X1)}

Arus Kas Operasi merupakan arus kas masuk dan arus kas keluar dalam periode tertentu dari kegiatan operasi.Perubahan arus kas dari aktivitas operasi merupakan selisih dari arus kas operasi periode tersebut dikurangi dengan arus kas operasi dari periode sebelumnya.

\section{Perubahan Arus Kas Investasi (X2)}

Arus kas investasi adalah jumlah arus kas bersih yang berasal dari perolehan dan pelepasan aktiva jangka panjang serta investasi lain yang tidak masuk setara kas. Perubahan arus kas dari aktivitas investasi merupakan selisih dari arus kas investasi periode tersebut dikurangi arus kas investasi dari periode sebelumnya dibagi dengan arus kas investasi dari periode sebelumnya.

\section{Perubahan Arus Kas Pendanaan (X3)}

Arus Kas Pendanaan merupakan arus kas yang diperoleh karena adanya kegiatan peminjaman dan pembayaran

hutang, perolehan sumber daya dari pemilik perusahaan, sertapemberian imbalan atas investasi bagi pemilik perusahaan.Perubahan aktivitas dari pendanaan merupakan selisih dari arus kas pendanaan periode tersebut dikurangi dengan arus kas pendanaan dari periode sebelumnya dibagi dengan arus kas pendanaan dari periode sebelumnya.

Return Saham (Y).

Return saham adalah hasil yang diperoleh dari investasi suatu saham. Hasil ini merupakan selisih antara harga saham periode saat ini dengan harga saham pada periode sebelumnya dibagi dengan harga saham periode sebelumnya (capital gainatau capital loss).

\subsection{Metode Pengumpulan Data}

Metode penelitian dalam penelitian ini menggunakan metode kuantitatif. Data berupa laporan keuangan perusahaan manufaktur yang di download dari website PT Bursa Efek Indonesia per 31 Desember periode 2012 sampai 2015.

\subsection{Populasi dan Sampel}

Populasi dalam penelitian ini adalah seluruh perusahaan manufaktur yang terdaftar di Bursa Efek Indonesia periode 2012 sampai 2015. Sampel dalam penelitian ini ditentukan dengan menggunakan metode purposive sampling.

\subsection{Teknik Analisis Data}


Pengujian hipotesis penelitian menggunakan metode analisis regresi linier berganda dengan bantuan program SPSS 20 for windows, sedangkan teknik analisis yang digunakan meliputi: (1) uji asumsi klasik yaitu untuk menguji kelayakan penggunaan model regresi (Ghozali, 2007). Uji asumsi klasik terdiri dari uji multikolinearitas, uji heteroskedastitas dan uji autokorelasi. (2) metode regresi berganda yang meliputi uji $\mathrm{t}$ (parsial) dan uji F (simultan).

\section{Hasil Penelitian}

\subsection{Hasil Uji Asumsi Klasik}

Dalam penggunaan analisis regresi linier bergandaperlu diketahui apakah pengunaan model regresi linierberganda tersebut telah memenuhi syarat asumsiasumsiklasik untuk menguji kelayakan terhadap
digunakan.Berdasarkan hasil pengujian didapat hasil bahwa regresi linier berganda layak untuk digunakan karena tidak menyimpang dari asumsi-asumsi klasik.Dimana data berdistribusi normal, tidak terdapat multikolinieritas, tidak terdapat heteroskedastitas, dan tidak terdapat autokorelasi, sehingga regresi berganda layak dan dapat digunakan dalam penelitian ini.

\subsection{Analisis Regresi Linier Berganda}

Analisis regresi linier berganda dimaksudkan untuk menguji sejauh mana dan arah pengaruh variabel independen terhadap variabel dependen. Variabel independen dalam penelitian ini adalah Arus Kas Investasi (AKO), Arus Kas Investasi (AKI), dan Arus Kas Pendanaan (AKP), sedangkan variabel dependennya adalah Return saham.

Tabel 1. Hasil Analisis Regresi Berganda

\begin{tabular}{crrr}
\hline & $\begin{array}{c}\text { Unstandardized } \\
\text { Coefficient }\end{array}$ & $\begin{array}{c}\text { Standardized } \\
\text { Coefficient }\end{array}$ & Sig \\
\hline Constant & 33,652 & & 0.000 \\
AKO (X1) & 0.009 & 0.516 & 0.004 \\
AKI (X2) & -0.006 & -0.031 & 0.852 \\
AKP (X3) & -0.021 & -0.143 & 0.388
\end{tabular}

Dependent Variabel: Return Saham (Y)

\subsection{Pengujian Hipotesis}

\subsubsection{Uji Koefisien Determinasi $\left(\mathbf{R}^{2}\right)$}

Koefisien determinasi $\left(\mathrm{R}^{2}\right)$ pada intinya mengukur seberapa jauh kemampuan model dalam menerangkan variasi variabel dependen. Nilai koefisien determinasi adalah antara nol dan satu $(0<$ $\mathrm{R}<1)$. Semakin besar koefisien determinasinya maka semakin besar variasi variabel independennya mempengaruhi variabel dependennya.Berdasarkan Tabel 1 diatas pada kolom Adjusted $R$ Square, 
diperoleh nilai koefisien determinasi sebesar 0,199 yang berarti, 19,9\% variabel return saham dijelaskan oleh perubahan variabel arus kas operasi, perubahan arus kas investasi, dan arus kas pendanaan secara bersama-sama, sedangkan sisanya dijelaskan oleh variabel lain yang tidak termasuk dalam penelitian ini.

\subsubsection{Hasil Uji Simultan (Uji F)}

Uji simultan (Uji F) bertujuan untuk melihat signifikansi pengaruh variabel independen secara bersama-sama terhadap variabel dependen. Berdasarkan hasil analisis pada Tabel 1 diperoleh nilai F hitung sebesar 3,564 dan F tabel sebesar 2,95 artinya $F$ hitung $>F$ tabel yaitu 3,564 $>$ pada sig 0,027 <0,05. Artinya, variabel arus kas operasi, arus kas investasi dan arus kas pendanaan secara bersama-sama mempunyai pengaruh signifikan terhadap return saham pada perusahaan manufaktur di Bursa Efek Indonesia.

\subsubsection{Hasil Uji Parsial (Uji t)}

Uji parsial (Uji t) digunakan untuk menguji pengaruh masing-masing variabel independen terhadap variabel dependen. Berdasarkan Tabel 1 hasil uji parsial untuk masing-masing variabel independen dapat dijelaskan sebagai berikut :

\section{Pengaruh Perubahan Arus Kas Operasi terhadap Return Saham}

Arus kas dari aktivitas operasi memiliki nilai signifikansi sebesar 0,004 yang berarti nilai ini lebih kecil dari 0,05 menunjukkan bahwa arus kas operasi memiliki hubungan yang searah dengan return saham. Jadi dapat disimpulkan bahwa secara parsial arus kas operasi berpengaruh positif dan signifikan terhadap return saham.Hasil penelitian ini mendukung hasil penelitian yang dilakukan oleh Trisnawati, Widya, \& Wahidahwati(2013) yang menjelaskan bahwa arus kas dari aktivitas operasi mempunyai pengaruh yang signifikan terhadapat return saham.Jumlah aruskas yang berasal dari aktivitas operasi menentukanapakah dari kegiatan operasinya perusahaandapat menghasilkan arus kas yang cukup untukmelunasi pinjaman, memelihara kemampuanoperasi perusahaan, membayar dividen danmelakukan investasi baru tanpa mengandalkanpada sumber pendanaan dari luar. Sehinggaadanya perubahan arus kas dari kegiatan operasiyang akan memberikan sinyal positif kepadainvestor, maka investor akan membeli sahamperusahaan yang pada akhirnya meningkatkanreturn saham.

\section{Pengaruh Arus Kas Investasi terhadap} Return Saham

Arus kas dari aktivitas investasi memiliki signifikansi sebesar 0,852 yang berarti nilai ini lebih besar dari 0,05. Jadi dapat disimpulkan bahwa secara parsial arus kas investasi tidak berpengaruh terhadap return saham.Hal ini 
mengindikasikan bahwa arus kas dari aktivitas investasi bukan merupakan informasi yang relevan bagi investor sebagai dasar pengambilan keputusan investasi. Hasil penelitian ini mendukung hasil penelitian yang dilakukan Utami (1999), dan Prasetyo (2003), serta Yocelyn, Azilia, \& Christiawan (2012) membuktikan bahwa tidak terdapat pengaruh yang signifikan arus kas investasi terhadap return saham. Namun penelitian ini tidak konsisten dengan penelitian Evi (2012) membuktikan terdapatpengaruh yang signifikan arus kas investasi dengan return saham.Arus kas dari aktivitas investasi dapat menjadisuatu pertimbangan bagi investor untukmenilai kinerja perusahaan di masa depan.Perusahaan dengan arus kas dari aktivitasinvestasi yang menurun, yang berarti adanyaaktivitas investasi, menunjukkan adanya potensikenaikan pendapatan di masa depat yangdiperoleh dari tambahan investasi baru tersebut.Informasi ini tentunya berguna bagi investor dandapat mempengaruhi keputusan membeli ataumenjual saham yang dimilikinya. Keputusaninvestor ini selanjutnya akan dapat menyebabkan perubahan harga saham dan return saham.

\section{Pengaruh Arus Kas Pendanaan terhadap Return Saham}

Arus kas dari aktivitas pendanaan signifikansi sebesar 0,388 yang berarti nilai ini lebih besar dari 0,05. Jadi dapat disimpulkan bahwa secara parsial arus kas pendanaan tidak berpengaruh terhadap return saham.Hal ini sejalan dengan penelitian yang dilakukan oleh Yocelyn, Azilia, \& Christiawan (2012)yang menyatakan bahwa arus kas dari aktivitas pendanaan berpengaruh positif dan tidak signifikan terhadap return saham.Arus kas pendanaan oleh investor belum digunakan sebagai pertimbangan dalam pengambilan keputusan berinvestasi dan investor beranggapan bahwa arus kas pendanaan yang tinggi mencerminkan bahwa perusahaan banyak mendapatkan tambahan dana dari sumber lain hal ini menunjukkan bahwa perusahaan belum terolah dengan baik sehingga resiko yang didapat dari investasi tersebut semakin besar dan juga keuntungan atau return yang didapat tidak banyak.

\section{Kesimpulan}

Berdasarkan hasil analisis data dan pembahasan hasil penelitian, maka dapat ditarik beberapa kesimpulan sebagai berikut: Arus kas operasi berpengaruh terhadap return saham pada perusahaan manufaktur yang terdaftar di Bursa Efek Indonesia. Arus kas operasi merupakan arus kas penghasil utama pendapatan perusahaan atau transaksi yang masuk atau keluar dalam penentuan laba bersih. Sehingga makin tinggi arus kas dari 
aktivitas operasi menunjukan bahwa perusahaan mampu beroperasi dengan baik. Arus kas investasi tidak berpengaruh terhadap returnsaham pada perusahaan manufaktur yang terdaftar di Bursa Efek Indonesia, hal ini dapat disebabkan karena arus kas dari aktivitas investasi bukan merupakan informasi yang relevan bagi investor sebagai dasar pengambilan keputusan investasi. Arus kas aktivitas pendanaan tidak berpengaruh terhadap return saham pada perusahaan manufaktur yang terdaftar di Bursa Efek Indonesia. Investor beranggapan bahwa arus kas pendanaan yang tinggi mencerminkan bahwa perusahaan banyak mendapatkan tambahan dana dari sumber lain, hal ini menunjukkan bahwa perusahaan belum terkelola dengan baik sehingga resiko yang didapat dari investasi tersebut semakin besar dan juga keuntungan atau return yang didapat tidak banyak. Variabel arus kas operasi, arus kas investasi dan arus kas pendanaan secara bersama-sama mempunyai pengaruh signifikan terhadap return saham pada perusahaan manufaktur di Bursa Efek Indonesia.

\section{Daftar Pustaka}

Ali, A. (1994). The Incremental Information Content of Earnings, Working Capital From Operations And Cash Flows. Journal of Accounting Research Vol 32 No 1, 61-73.
Cahyani. (1999). Muatan Informasi Tambahan Arus Kas Dari Aktivitas Operasi Investasi dan Pendanaan. Jurnal Bisnis dan Akuntansi Volume 1 Nomor 1, 15-27.

Daniati, Ninna, \& Suhari. (2006). Pengaruh Kandungan Informasi Komponen Laporan Arus Kas, Laba kotor dan Size Terhadap Expected Return Saham. SNA IX Padang.

Evi, M. (2012). Pengaruh Informasi Laba dan Arus Kas Terhadap Harga Saham. Jurnal Akuntansi, Volume 1 Nomor 1.

Ghozali, I. (2007). Analisis Muktivariate dengan Program SPSS. Semarang: Universitas Diponegoro.

Hadi, S. R. (2013). Sukses Membeli Saham Tanpa Modal. Jakarta: Laskar Aksyara.

Hartono, J. (2013). Teori Portofolio dan Analisis Investasi. Yogyakarta: BPFE.

Kurniawan, \& Indriantoro. (2000). Analisis Hubungan Antara Arus Kas Operasi dan Data Akrual dengan Return Saham. Jrunal Bisnis dan Akuntansi Volume 2 Nomor 3, 207224.

Livnat \& Zarowin. (1990). The Incremental Information Content of Cash Flow Component. Journal of Accounting and Economic, 13.

Pradhono \& Setiawan, Y. J. (2004). Pengaruh EVA, Residual Income, Earning dan Arus Kas Operasi Terhadap Return Yang diterima oleh Pemegang Saham. Jurnal Akuntansi dan Keuangan Volume 6, 140-163.

Prasetyo, J. (2003). Analisa Pengaruh Interakti Laba Dengan Laporan Arus Kas Terhadap Return Saham. Jurnal Wahana, Volume 6 Nomor 1, Pebruari. 
Subramanyam \& Jhon. (2011). Analisis Laporan Keuangan. Jakarta: Salemba Empat.

Trisnawati, Widya, \& Wahidahwati. (2013). Pengaruh Arus Kas Operasi, Investasi dan Pendanaan Serta Laba Bersih Terhadap Return Saham. Jurnal Ilmu dan Riset Akuntansi, Volume 1 Nomor 1.

Utami, D. (1999). Muatan Informasi Tambahan Arus Kas Dari Aktivitas Operasi, Investasi dan Pendanaan. Jurnsl Bisnis dan Akuntansi, Volume 1 Nomor 1 April.

Yocelyn, Azilia, \& Christiawan. (2012). Analisis Pengaruh Perubahan Arus Kas dan Laba Akuntansi Terhadap Return Saham Pada Perusahaan Berkapitalisasi Besar. Jurnal Akuntansi dan Keuangan, Volume 14 Nomor 2. 